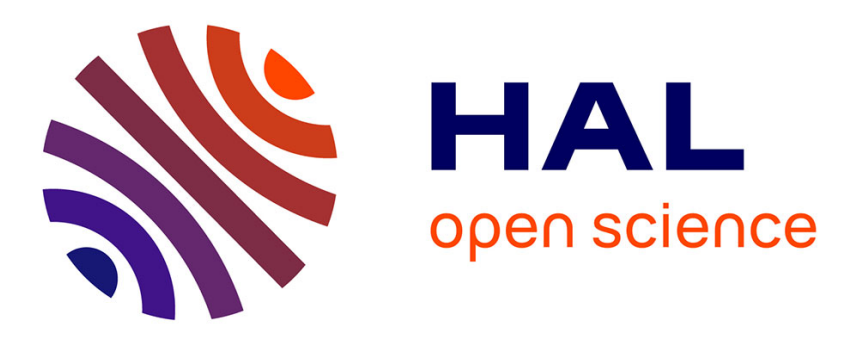

\title{
Phytosulfokine-alpha, an enhancer of in vitro regeneration competence in recalcitrant legumes
}

Sergio Ochatt, Catherine Conreux, Guillaume Despierre, Jean-Bernard

Magnin-Robert, Blandine Raffiot

\section{- To cite this version:}

Sergio Ochatt, Catherine Conreux, Guillaume Despierre, Jean-Bernard Magnin-Robert, Blandine Raffiot. Phytosulfokine-alpha, an enhancer of in vitro regeneration competence in recalcitrant legumes. 8. International Conference on Legume Genetics and Genomics (ICLGG), Noble Research Institute., Sep 2017, Siófok, Hungary. 128 p. hal-02734065

\section{HAL Id: hal-02734065 https://hal.inrae.fr/hal-02734065}

Submitted on 2 Jun 2020

HAL is a multi-disciplinary open access archive for the deposit and dissemination of scientific research documents, whether they are published or not. The documents may come from teaching and research institutions in France or abroad, or from public or private research centers.
L'archive ouverte pluridisciplinaire HAL, est destinée au dépôt et à la diffusion de documents scientifiques de niveau recherche, publiés ou non, émanant des établissements d'enseignement et de recherche français ou étrangers, des laboratoires publics ou privés. 


\section{BOOK OF \\ ABSTRACTS}
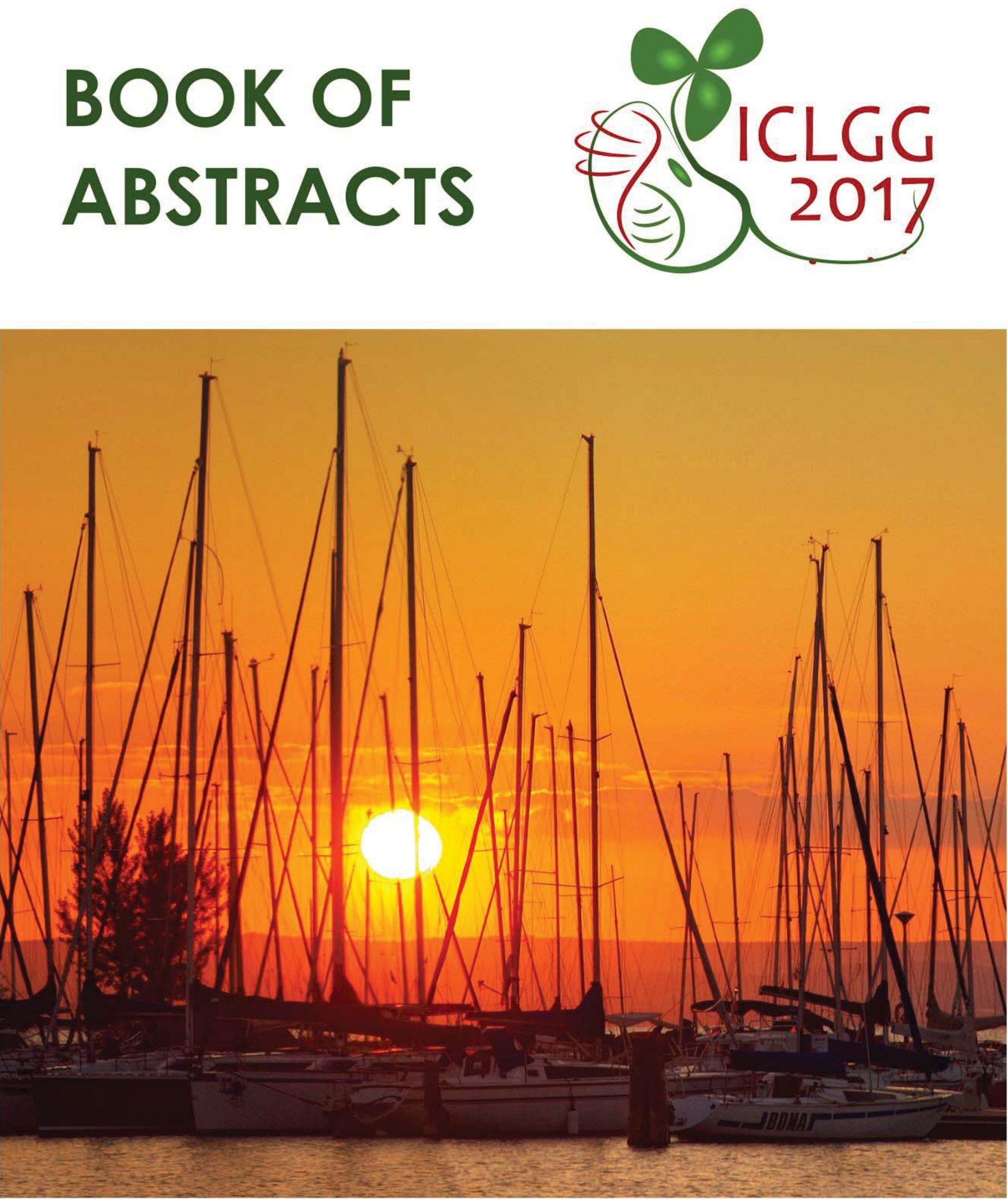

$8^{\text {th }}$ International Conference on Legume Genetics and Genomics 18-22 September 2017

Siófok, Hungary 


\title{
Phytosulfokine-alpha, an enhancer of in vitro regeneration competence in recalcitrant legumes
}

\author{
S.J. Ochatt, C. Conreux, G. Despierre, J.B. Magnin-Robert, B. Raffiot
}

Agroécologie, Agrosup Dijon, INRA, Univ. Bourgogne Franche-Comté, Dijon, France

Oligopeptides have been recognized as signalling molecules playing an important role in plant cell growth and development. Phytosulfokine-alpha (PSK), a plant-specific disulfated pentapeptide, is involved at nanomolar concentrations in initial steps of cellular dedifferentiation, proliferation, and redifferentiation, with a biological function similar to that of plant hormones. On the other hand, legume crops are generally known for their recalcitrance to in vitro regeneration approaches, which has restrained the exploitation of biotechnological tools for their genetic improvement.

Against this background, we added PSK at concentrations of $10^{-10}$ to $10^{-6} \mathrm{M}$, to semisolid MS-based culture media previously shown to permit some regeneration responses with a number of genotypes of pea (Pisum sativum), Medicago truncatula and also the highly recalcitrant faba bean (Vicia faba).

Callus, cell suspensions and embryo-derived explants of barrel medic R108, pea cvs Frisson and Cameor and a zero vicin, zero tannin faba bean genotype were tested and their embryogenic and organogenic regeneration competence was assessed. PSK had a strong and significant enhancing effect on the regeneration competence of all genotypes, producing somatic embryos and organs that yielded regenerated plants of both pea and $M$. truncatula, and with a major organogenic effect leading to plant regeneration with faba bean where somatic embryos, although produced, failed to convert into viable plants. This is the first report on the use of PSK with legume species.

How to refer your abstract:

S.J. Ochatt, C. Conreux, G. Despierre, J.B. Magnin-Robert, B. Raffiot (2017) Phytosulfokine-alpha, an enhancer of in vitro regeneration competence in recalcitrant legumes; ICLGG 2017 - Book of abstracts, ICLGG2017/P/26 